\title{
Addressing and acknowledging readers and writers. Exploring metadiscourse in opinion writing online
}

\section{Ylva Biri}

University of Helsinki

ylva.biri@helsinki.fil

\begin{abstract}
Effective opinion writing should present the author's viewpoint in a convincing way but also engage the reader. Whether the author makes more references to their own viewpoints or to the reader is determined by the context of the text. Metadiscourse is a pragmatic framework of explicit linguistic devices used to make references to the reader, the writer and their evaluations, as well as references to the textual organisation. This paper employs the corpus-driven method called Multi-Dimensional Analysis to study statistically significant correlation patterns between metadiscourse markers. Four patterns emerge from a specialized corpus of opinion writing online in English by (semi-)professional writers (285,000 words). The patterns are interpreted as representing writers' strategies to define the relationship between themselves, the reader and the topic. While there are some overlaps and cross-genre tendencies, the use of metadiscourse is to some extent determined by the prevailing norms of the sub-genre of the text-here, whether the publication platform is a blog, a news site, or the website of a print-newspaper. Blogs tend to use a writer-oriented strategy with more self-mentions, and news sites a reader-oriented strategy or a solidarity strategy uniting the reader and writer under a shared "we"-pronoun. The results of the study may be of value both in understanding the journalistic online genres and for the development of the metadiscourse framework.
\end{abstract}

Keywords: metadiscourse, multi-dimensional analysis, opinion writing, online discourse, reader-writer relationship.

Sposoby zwracania się do czytelników i autorów i uznawania ich roli. Badanie metadyskursu przy pisaniu opinii umieszczanych w sieci

Streszczenie

Skutecznie napisana opinia powinna $w$ przekonujacy sposób przedstawiać punkt widzenia autora, ale téz $i$ angażować czytelnika. To, czy autor czyni więcej odniesień do swoich punktów widzenia czy do czytelnika zależy od kontekstu pojawienia się danego tekstu. Metadyskurs stanowi pragmatyczna strukture jawnych strategii lingwistycznych wykorzystywanych do tworzenia odniesień do czytelnika, do autora i do ich sąów, jak również tworzenia odniesień do organizacji tekstualnej. W niniejszym artykule wykorzystano metode wielowymiarowej 
analizy (Multi-Dimensional Analysis) do zbadania statystycznie istotnych wzorców korelacji między znacznikami metadyskursowymi. Badanie specjalistycznego korpusu pisania online opinii po angielsku przez (pół) profesjonalnych autorów (285000 stów) wytoniło cztery wzorce. $W$ zaproponowanej tu interpretacji reprezentuja one strategie autorów, majace na celu zdefiniowanie relacji między nimi samymi, czytelnikiem a tematem. Mimo zazębiania się $i$ istnienia tendencji międzygatunkowych, uzycie metadyskursu jest $w$ pewnym stopniu zdeterminowane przez obowiąujące normy podgatunku tekstu - tutaj, na przykład określenie czy platforma publikacji jest blogiem, portalem z wiadomościami lub strona internetowa gazety

drukowanej. Blogi zazwyczaj wykorzystuja strategię nakierowana na autora, z większa ilościa auto-odniesień. Z kolei portale informacyjne stosuja strategie zorientowana na czytelnika, lub też strategię solidarnościowa, tacząca czytelnika i autora w inkluzyjnym zaimku "my". Wyniki badania moga mieć wartość zarówno w zrozumieniu dziennikarskich gatunków internetowych, jak $i$ dla rozwoju ram metadyskursywnych.

Słowa kluczowe: metadyskurs, analiza wielowymiarowa, pisanie opinii, dyskurs online, relacja autor-czytelnik.

\section{Introduction}

For readers to heed to a text, the text needs something to make its content engaging but also well-organized for the audience. Metadiscourse is a pragmatic framework for describing explicit, linguistic devices for organizing the text flow, engaging the audience, and expressing the author's stance. Following the definitions of researchers including Vande Kopple (1985), Crismore et al. (1993) and Hyland (2005), metadiscourse is linguistic material that does not add to the propositional content, only evaluates or organises it (Crismore et al. 1993: 40). Being a set of explicit devices in a text, metadiscourse is thought to represent the conscious efforts of a writer to reach their audience, but also to reflect the "norms and expectations of particular cultural and professional communities" wherein the text is set (Hyland 1998). Metadiscourse is thus argued to have a strong persuasive function in argumentative essays (e.g. Crismore et al. 1993), advertising (e.g. Fuertes-Olivera et al. 2001), editorials (e.g. Dafouz-Milne 2003; Le 2004), popular science and newspaper opinion texts (Fu, Hyland 2014), and more. The present study aims to compare the uses and functions of metadiscourse in opinion writing in newspapers, news sites and blogs.

While many studies on metadiscourse do use corpus methods, to my knowledge only Zhang (2017) uses Multi-Dimensional Analysis (MDA) as a method to study metadiscourse. Developed by Biber (1988), MDA is a corpus-driven method based on Factor Analysis for examining correlations among linguistic variables. Analysing correlations through a statistical 
corpus-driven method allows for a description of the genre that is unavailable for studies with qualitative methods or studies with pre-determined frameworks. Whereas Zhang's (2017) corpus is the general Freiburg Lancaster-Oslo-Bergen Corpus of 1 million words, the corpus of the present study is a small specialised corpus - and whereas Zhang compares several genres, the goal of this paper is to explore the variation within one genre, namely professional opinion writing (e.g. columns, op-eds) in online sources, blogs, news sites and in newspapers. The research questions are thus:

RQ1: How do different metadiscourse marker categories correlate with each other in online opinion texts?

The underlying assumption of MDA is that co-occurring linguistic variables represent a pragmatic function. For metadiscoursal variables, the function is related to engaging and organizing purposes. The results of this research question provide basis for the second question:

RQ2: How does the use of the functions vary in opinion writing on blogs, on news sites and in newspapers?

Using quantitative empirical data, the study aims to provide insight in the journalistic online opinion writing genre and in variation within this genre, as well as in the use of metadiscourse and the metadiscourse framework itself.

\section{Blogs, news sites, and newspapers}

A key focus of the present study is to compare the linguistic registers of opinion writing published on three online platforms: blogs, news sites and newspapers. Opinion writing published in these three online settings can easily be thought of as essentially fairly similar. The affordances of the online setting include the storing of the text online and making the text available for a global audience that could potentially include anyone with internet access. On all three platforms, the text can make use of images, multimedia, hyperlinks, as well as a comment field where readers may leave a response or feedback to the author. Furthermore, with the genre to be studied being limited to opinion writing, the texts themselves can be thought of as sharing the same set of goals: to express an opinion, to argue for a cause, or to persuade the reader. However, whether the apparent similarities are reflected in the register used in the settings warrants empirical research. The following outlines some of the key characteristics and differences between the three platforms.

Blogs, or weblogs, are the websites of an individual, a platform for self-publishing text or media: some blogs may be upheld by a group of individuals, even an organization, that publishes 
content related to its operations. Thematically, blogs can cover just about any topic, entertainment, personal life, lifestyle or how-to: however, the ones examined in the present study all focus on discussing political or societal topics. Blogging, when understood as the author upholding their own site, has increasingly shifted to micro-blogging and other social media platforms (see Lenhart et al. 2010: 24), but on the other hand, many who still uphold their own blogs feel the need for increased professionalism. Blogs are still largely seen as personal diarylike platforms, but at least the Scandinavian bloggers observed by Pinjamaa and Cheshire (2016) report that blogs are becoming increasingly professionalised and commercialised with carefully planned and edited publications.

As for opinion writing in online newspapers, most if not all print newspapers today also have a website where they publish content. The online versions of newspapers may serve to reach out to more readers, but it may also be a financial decision (e.g. to save money in printing) or a way to allow for publishing news that is more geographically or demographically specialised, that is, to reach out to a more specialised group of readers (Tewksbury 2005). Today there are also news sites, news outlets based solely online, without a printed publication. In fact, De Waal and Schoenbach (2010: 481) argue that digitally native, online-only news sites succeeded in creating progressive websites for news before the established newspapers: news sites were thus pioneers in designing interactive and user-oriented websites. Yet in terms of function, rather than being a genre that has emerged from or even been noticeably reconfigured for Web 2.0, news sites are better thought of as a form of the news genre which has simply been reproduced for the online setting (see Herring, 2013: 7). When compared to traditional newspapers, news sites have been seen by users as particularly good sources for so-called soft news, on crime or culture. However, while there are digital-only news sites such as Huffington Post, BuzzFeed and Business Insider with massive readerships and revenues, most news sites are local and rely on advertising revenue. In 2015 only 47\% digital news publishers reported turning a profit (Lu, Holcomb 2016: 59).

Both in newspapers and on news sites, opinion writing by journalists who are not part of the editorial board may take form of columns and op-eds. Besides presenting an opinion, the goal may also be to give a factual report that is then evaluated in an interpretive report (Rivers et al. 1998: 8). According to Greenberg (2000), columns and op-eds encourage the reader to form their own opinion despite the evaluative stance. For blogs, Wall (2005) notes that reporting in blogs can be more opinionated than traditional journalism, but despite this and the fact that blogs are still edited only by the blogger themselves, more recent studies argue that blogs often 
soften their claims (Myers 2010: 120) and acknowledge different perspectives of an issue (Reese et al. 2007: 277).

According to the definition set out by Swales (1990: 46), texts belong to the same genre if they share a communicative purpose or set of purposes. What op-eds and columns from newspapers and news sites and societal commentary blogs all have in common is their purpose of (1) conveying the author's opinion on a particular matter, and typically also (2) persuading the reader of the author's viewpoint and (3) reporting the news for which they provide a viewpoint. While newspaper or news site columns and blogs may be different in terms of the setting in which they are published (a news source edited by a copy-editor contrasted to a selfedited blog), they are all more or less formal online texts in written form that represent the viewpoint of the author. Opinion writing from blogs and news sources can thus be argued to represent the same broad genre. A key difference is the fact that while the audience of a newspaper or news site may be specialised, the audience of a blog is usually more familiar than the audience of a journalist, even becoming something of a "co-creator" as the blog's readers may be involved in the contribution of information and feedback (Wall 2005: 161).

\section{Metadiscourse}

Metadiscourse is a pragmatic and rhetorical device writers and speakers use to organize and comment the propositional content. Referring to elements of a text itself, interactive metadiscourse (Hyland, Tse 2004) is text-organising, "reader-friendly" metadiscourse (Thompson, Thetela 1995), used to ensure readability and understanding of a text. Devices include grammatical cohesive devices (e.g. however, in addition), explicating comments (e.g. in other words, for example) and references to elements in the discourse (e.g. the figure below, in summary) or discourse goals (e.g. to summarise). On the other hand, referring to participants in a text as an event, interactional metadiscourse (Hyland, Tse 2004) is engaging or "readermanaging" metadiscourse (Thompson, Thetela 1995) that addresses the reader or acknowledges the presence of the author. Devices include first- and second-person pronouns to refer to the participants of the discourse event, rhetorical questions, attitudinal markers to mark author's evaluation (e.g. fortunately, I hate...), and Hedges and Boosters to soften or strengthen the epistemicity of the author's claims (e.g. perhaps, clearly). Dafouz-Milne argues that both interactive and interactional metadiscourse are concerned with persuasion of the reader, with interactional simply being more explicit in its function. By using interactive metadiscourse "he/she is trying to transmit a sense of conviction, authority and rationality (Dafouz-Milne 2003: 
33). The sense of interactive metadiscourse conveying authority is also noted by Mauranen (1993: 167). Interactive metadiscourse as a form of persuasion is frequent in academic writing (see e.g. Hyland 1998), for example, but due to the lengthy and complex nature of academic texts, interactive metadiscourse is also a necessity for the readers to be able to follow the arguments more easily. It therefore unsurprising that less complex and specialised texts, such as editorials (see Dafouz-Milne 2003; Le 2004), contain less interactive metadiscourse. Indeed, the use of metadiscourse is strongly linked with the norms and expectations of the genre (Hyland 1998: 438). In genres directed towards a general audience, the expectations that the author must meet in order to achieve their goals are then determined by the audience (Fu, Hyland 2014)

The framework of metadiscourse of the present study draws mainly from the frameworks of Crismore et al. (1993), Hyland and Tse (2004) and Dafouz-Milne (2003, 2008). Some researchers (e.g. Mauranen 1993; Ädel 2006) define metadiscourse more narrowly, only counting markers with a text-reflexive organisational purpose, excluding the functionally distinct interactional metadiscourse from the scope of their frameworks. The framework for the present study follows the so-called broad approach, which includes both interactive and interactional metadiscourse, and consists of the 13 categories presented in Table 1:

Table 1. Metadiscourse framework based on Hyland and Tse (2004), Dafouz-Milne (2008)

\begin{tabular}{|c|c|c|c|}
\hline & Metadiscourse & Function & Examples \\
\hline \multirow{3}{*}{ 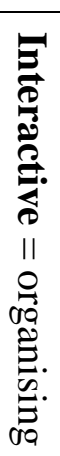 } & Transitional markers & $\begin{array}{l}\text { link signal additive or } \\
\text { comparative relations } \\
\text { between arguments }\end{array}$ & $\begin{array}{l}\text { moreover; but; because; } \\
\text { thus }\end{array}$ \\
\hline & Textual Organisers & $\begin{array}{l}\text { organise and refer to } \\
\text { sections, section-order or } \\
\text { images; mention topic } \\
\text { shifts and discourse goals }\end{array}$ & $\begin{array}{l}\text { the following; secondly; } \\
\text { click here; to conclude; I } \\
\text { argue; Let's switch to... }\end{array}$ \\
\hline & Code Gloss & $\begin{array}{l}\text { elaborate or define } \\
\text { meaning; give examples }\end{array}$ & $\begin{array}{l}\text { for instance; such as; } \\
\text { that is; in other words }\end{array}$ \\
\hline \multirow{5}{*}{ 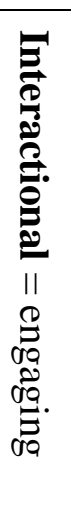 } & Attributors & $\begin{array}{l}\text { link statement to source of } \\
\text { information }\end{array}$ & $\begin{array}{l}\text { say; suggest that; } \\
\text { according to }\end{array}$ \\
\hline & Hedges & $\begin{array}{l}\text { withhold commitment to } \\
\text { statement; approximate }\end{array}$ & $\begin{array}{l}\text { perhaps; it's possible; } \\
\text { seem to; might; nearly }\end{array}$ \\
\hline & Boosters & $\begin{array}{l}\text { emphasise certainty or } \\
\text { truth value of statement }\end{array}$ & $\begin{array}{l}\text { it's clear; obviously; we } \\
\text { know; is proof that }\end{array}$ \\
\hline & Attitude markers & $\begin{array}{l}\text { express author's affective } \\
\text { attitude to propositions }\end{array}$ & $\begin{array}{l}\text { unfortunately; it's bad } \\
\text { that...; I love; I believe }\end{array}$ \\
\hline & Reader address & $\begin{array}{l}2^{\text {nd }} \text {-person pronouns; } \\
\text { directives to reader }\end{array}$ & you, your; observe; click \\
\hline
\end{tabular}




\begin{tabular}{|l|l|l|l|}
\hline Self-mention & $\begin{array}{l}\text { 1SG or 1PL, explicit } \\
\text { reference to author(s) }\end{array}$ & $\begin{array}{l}\text { I, me, my; we, our } \\
\text { (excluding where used } \\
\text { as attitude marker) }\end{array}$ \\
\cline { 2 - 4 } Inclusive We & $\begin{array}{l}\text { 1PL referring to both } \\
\text { author and reader }\end{array}$ & $\begin{array}{l}\text { we, our, us } \\
\text { modals and semi-modals } \\
\text { marking necessity }\end{array}$ & $\begin{array}{l}\text { must; need to; should } \\
\text { not, ought to }\end{array}$ \\
\cline { 2 - 4 } Deontic Modals & $\begin{array}{l}\text { rhetorical questions asked } \\
\text { from the reader. }\end{array}$ & $\begin{array}{l}\text { Remember } \\
\text { Right? }\end{array}$ \\
\hline Commentary & $\begin{array}{l}\text { appositions in parentheses } \\
\text { or dashes (see Dafouz- } \\
\text { Milne 2003: 38); } \\
\text { conversational devices }\end{array}$ & $\begin{array}{l}\text { yeah wow; the truth (if } \\
\text { you call it that) is... }\end{array}$ \\
\hline
\end{tabular}

Metadiscourse is limited to linguistic, explicit, non-propositional devices. It is not interested in punctuation, font or layout. Neither does it consider implicit devices such as metaphors, or propositional content, that is, information relating to participants or events of the narrative or the description itself, the non-metalevel. In Hallidayan Systemic Functional terms (Halliday 1973), metadiscourse represents the textual and the interpersonal functions of language, the organisation and the writer-reader relationship, but not the ideational function concerned with the factual content. For example, the affective lexeme in the hypothetical Example 1a (italicized) evaluates the following proposition (in brackets) and is therefore metadiscoursal; in $1 \mathrm{~b}$ the word as a modifier within the proposition is not metadiscoursal.

(1) a. It is wonderful that [they could join us].

b. It is a wonderful day.

Given the restricted focus of the framework, a low frequency of, say, Attitudinal metadiscourse does not imply that a text is lacking in attitude, only that it may be expressed elsewhere, in implicit or propositional ways such as through metaphors or word choice. As suggested by Khabbazi-Oskouei (2013), one way of distinguishing propositional from non-propositional attitudinal metadiscourse is to count only attitude separated from the main clause, as framing clausal adverbials rather than modifiers within the clause, although Ifantidou (2005: 1338) argues that they, too, may contribute to the proposition. For the sake of facilitated corpus tagging but also to increase systematicity of the analysis across all texts, the present study will consider framing items as metadiscourse. However, care is taken for markers such as here or now to be tagged as metadiscourse only if they refer to the elements of a text or discourse event and not to the propositional content of the text. 


\section{Data and methods}

As the goal of the present study includes investigating the correlation between multiple variables and to determine the extent of variation within a seemingly homogenous genre, a multivariate statistical method was deemed the best option for determining the correlation patterns. Based on Factor Analysis (FA) but developed for variational linguistics by Biber (1988), MultiDimensional Analysis (MDA) is ideal for analyses in genre register variation where correlation among variables is of interest. The method assumes that the correlation of a group of variables is due to an underlying variable, a shared or overarching function, and that descriptions of a register can be based on these underlying variables interpreted as linguistic functions. In short, the method enables the reduction of large number of variables to a smaller number of variables. The main advantage of MDA is thus its facilitation of the finding of patterns across large number of variables in a large amount of data, a task impossible or at least painstaking if done by eye and hand. On the other hand, comparison across parameters allows the description of texts across broader continua rather than in terms of the frequencies of individual features. The analysis is often done for large corpora, but it is also possible to use on a smaller sample, provided that the data contains enough variation. For more details on the theoretical underpinnings of the method, see Biber (1988).

\subsection{Data}

The corpus collected for the purposes of this study is a specialized corpus of op-eds, columns and blog posts from various news sites, online newspapers, and blogs discussing societal, political or ideological issues. The main selection criterion is traffic and the sources have been selected from website traffic tracker by Alexa Internet, Inc. (alexa.com/topsites), from among the top sites in categories News>Analysis and Opinion, News>Weblogs, and Society $>$ Politics $>$ News and Media. The final corpus consists of 343 texts from 27 different sources, amounting to a total of 285,056-word tokens collected in October-November 2016. All sources are in English and based in English-speaking countries; the criteria of website traffic led to most sources being based in the United States. The use of a more geographically balanced corpus would likely reveal trends not applicable in the results of the present study. It should further be noted that the high traffic blogs collected for the corpus are upheld mainly by experienced writers and the news sites are assumed to be run by professional journalists. Hence this corpus, and by extension the findings of this study, is representative of opinion writing by (semi-)professional writers rather than of opinion writing on small, personal and amateur blogs. 
As many metadiscoursal categories are not limited to a single lexical category or syntactic construction, the corpus was annotated by combining of automatic and manual annotation in the UAM CorpusTool software, a corpus annotation tool suitable for assigning segments of text with multiple tags on several layers (O’Donnell 2008). When deciding what lemmas or constructions could mark metadiscourse, lists of potential markers were compiled by reviewing previous literature (especially Hyland [2005], whose Appendix has a lengthy list of potential markers in academic writing), but also from the corpus of the present study itself, by extracting word-lists that were surveyed for potential markers.

\subsection{Method}

After the corpus had been tagged, a FA on the variables was conducted using the factoextra package (Kassambra, Mundt 2017) for the R programming language. The Kaiser-Meier-Olkin (KMO) index, used for determining whether the variation and correlation in the sample is suited for $\mathrm{FA}$, indicated that the data was fit for FA $(\mathrm{KMO}=0.608)$. Factors were extracted through Promax rotation, an oblique rotation appropriate when factors are assumed to be dependent of each other as is the case with linguistic variables (Biber 1988: 85). A four-factor solution was found optimal for a statistically significant analysis $(\chi 2=51.29 ; \mathrm{df}=32$; $\mathrm{p}$-value $=0.0167)$. Cumulatively, the four factors explain $70.7 \%$ of the total variance. Table 2 gives the factorial structure with variables above 0.1 . A variable can be counted as belonging only in one factor: parentheses mark variables load on the dimension but score higher elsewhere.

Table 2. Extracted factors and variable loadings above 0.1

\begin{tabular}{|ll|ll|}
\hline Factor 1: & & Factor 3: & \\
Attitude markers & 0.748 & Reader address & 0.701 \\
Self-mentions & 0.468 & Questions & 0.407 \\
Transitional markers & 0.414 & Textual Organisers & 0.321 \\
Hedges & 0.348 & Commentary & 0.210 \\
Boosters & 0.230 & (Self-mention) & $(0.146)$ \\
(Deontic modals) & $(0.200)$ & (Boosters) & $(-0.110)$ \\
(Attributors) & $(-0.124)$ & Code gloss & -0.219 \\
& & & \\
Factor 2: & & Factor 4: & \\
Inclusive We & 0.983 & Attributors & 0.620 \\
Deontic modals & 0.253 & (Transitional & $(0.256)$ \\
(Self-mention) & $(-0.109)$ & markers) & $(0.118)$ \\
(Textual organisers) & $(-0.113)$ & (Boosters) & $(-0.158)$ \\
& & (Self-mention) & $(-0.137)$ \\
& & (Textual organisers) & $(-0.197)$ \\
\hline
\end{tabular}


Variables in FA are considered to belong only in the dimension where their absolute factor loading is the highest. Although Biber (1988: 93) uses a conservative cut-off point of \pm 0.35 , here all variables with factor loadings over \pm 0.30 were retained. Three metadiscoursal functions did not score highly on any dimension and will thus be left outside further analysis. Sometimes non-loading variables should be discarded from the entire data, but Pett et al. (2003: 173) argue that variables can be retained if they are crucial to the subset of a study. Because of the low number of variables and the relatively low frequency of some of the variables, the present study retains all original 13 variables so as to retain the interconnectedness of all variables. However, four variables did not load high enough on any dimension and the discussion below focuses only on the remaining nine variables that do load on a factor.

Assuming that frequencies in the corpus follow a Gaussian normal distribution, Z-scores are calculated for each variable in each text as $\mathrm{Z}=($ frequency - mean $) /$ standard deviation. From this a factor score is calculated for each text in the corpus. The factor score of a factor is the sum of the Z-scores of each variable in the factor. The score indicates how much or how little a factor is represented in the text. A score of 0 being the mean, a positive score represents representation above mean and a negative representation below mean. Biber (1988) and other studies following his goal to compare entire genres or sub-genres use the factor scores to calculate a mean dimension score for each genre, that is, how much a factor is represented in the genre as a whole. As the aim of the present study is to describe variation within one genre, the analysis here focuses on factor scores for individual texts in order to gauge both trends and outliers.

\section{Analysis}

A factor extracted through a FA is not meaningful until its functions have been interpreted based on the functions of the variables that load on the factor. The variables with the highest loadings should play the greatest role in the interpretation. A MDA also calls for a qualitative closerreading of selected samples to complement the quantitative findings. Having analysed concordances of the metadiscourse markers, the dimensions are interpreted as having the following pragmatic functions:

1. Writer-oriented

2. Solidarity-oriented

3. Reader-oriented 


\section{Intertextuality}

The functions can be seen as a rhetorical strategies for creating an author's ethos (Crismore, Farnsworth 1989; Mauranen 1993). The first three functions represent interaction between the author and the audience whereas the fourth function represents how the text connects to other discourse. The functions will be further defined and explained in the following sub-sections.

\subsection{Writer-oriented function}

Factor 1 consists of four metadiscourse marker categories: attitude markers, self-mentions, transitional markers and hedges. With the exception of transitional markers, the markers relate to expressing or modifying the writer's opinion or otherwise acknowledging the author's presence. The factor is thus seen as having a Writer-oriented function. The attitude markers category includes both adverbs such as unfortunately but also verbs for emotional or cognitive processes, I love, I believe. Hedges are used to soften a statement: as argued by Fu and Hyland (2014), hedging may add to the persuasive effect by concealing the persuasive function and increasing the reasonableness of a statement. On the other hand, in news reporting or commenting, hedges often hypothesise future events and developments as in the example below, where the blogger theorizes tongue-in-cheek what might happen in the upcoming debate between the 2016 US presidential candidates (Hedges and Transitional markers have been italicized):

(2) Maybe in the next debate she'll bring the knife. And maybe he'll actually prepare. But that's probably expecting too much of him (Mahablog.com: 27.9.2016).

Meanwhile, self-mentions are first-person pronouns (not counting where the pronoun appears as part of an Attitude marking construction). At times the pronoun relates more to the writer in their position as the author of the text (e.g. I analyse, I argue), but by discussing the real experiences of the writer, they may refer to the writer as a text-external or autobiographic self (Ädel 2006: 30-31). Nevertheless, both types of self-mention acknowledge the presence of the writer as an individual experiencer and as an evaluating author. In the example below the author comments on the events by saying what they would do as a private person, but also as an evaluator who is sharing their thoughts with the reader (metadiscourse italicized): 
(3) I would stand up for the anthem because it is the right thing to do, but I completely understand why Colin [Kaepernick] did what he did and why he will continue to do so (Bloggernews.net: 14.9.2016).

Transitional markers may intuitively be seen as having only an organisational function, but as argued by Thompson and Hunston (2000: 9), "less obtrusive" evaluation may be more successful in manipulating the reader. Moreover, transitional markers connect the author's propositions into an evaluative argument and the arguments into a coherent narrative. In the example above, a statement is linked to a reason with the subordinator because and to a sign contrasting or unexpected conclusion with the coordinator but. While transitional markers hardly have an inherent link to the writer-oriented function as opposed to any other rhetoric, the fact that they load higher on Dimension $1(0.414)$ than on any other factor is an interesting finding. A closer reading focusing on transitional markers could shed some light on the seemingly unexplainable statistical significance.

\subsection{Solidarity-oriented function}

Factor 2 consists of only one marker, the inclusive we, that is, 1PL-pronouns referring to both the writer's self and the reader as opposed to only the writer. While Ädel (2006) and Zhang (2016) note the need for distinction between inclusive and exclusive first-person pronouns, Hyland's (2005) framework marks all first-person pronouns as self-mentions. The results of the present study also provide support for that the inclusive and exclusive 1PL-pronouns should be treated as separate, although such annotation must admittedly be conducted manually. While we in its reader-excluding meaning frequently refers to the author and their family or team of coworkers in an autobiographical narrative, the reader-inclusive we is almost exclusively used in contexts where it refers to the people of a nation or a party, as in the example:

(4) Our politicians and media have totally obscured the truth behind these and subsequent attacks that we call 'terrorism' (EricMargolis.com: 10.9.2016).

Here the pronoun is used create a sense of unity among a nationality (here, the US). Indeed, most instances of the we-pronoun are used in similar rhetoric: a group of citizens is united under our country or even under a phrase like we are at war, where we is understood as referring to the nation or its government. The factor is thus termed Solidarity-oriented. The characteristics 
that people in the group are assumed to share are further defined in the phrase "that we call 'terrorism"”.

It should be noted that while deontic modals (must, need to) are not part of Factor 2, they often collocate with inclusive we as calls to action, urging the reader to do something. In $u s$ liberals, the actual reader may not fit the role inscribed to the implied reader, but with the inclusive we the rhetorical strategy seeks common ground. While engaging the reader by bringing the topic closer to home, the author also reminds that they themselves, too, are part of the home team at whom the commissive is directed for the purpose of inciting agreement or action.

\subsection{Reader-oriented function}

Three categories load on Factor 3: reader-address, questions and textual organisers. Readeraddress includes both second-person pronouns and directives and forbiddances directed towards the reader. Questions may be directed towards the reader as real or rhetorical questions, but they may also be used to introduce new ideas or topics as questions that a hypothetical reader might be asking the writer. In their topic-introducing function they resemble textual organisers, the main function of which is to order sections or otherwise structure the arguments. Guiding the reader's comprehension, textual organisers may refer to other paragraphs or arguments, to images or links, or to prepare the reader for a discursive action (to summarise, let me repeat). Because all three metadiscourse marker categories in Factor 3 have some reader-related function, the dimension is here termed Reader-oriented. Consider for instance the following:

(5) Now I know this is a small-scale example. But think about the same principle on a larger scale. What happens when technology is advanced enough to cook, prepare, and serve your Big Mac meal too? (Bloggernews.net: 5.10.2016).

The initial now primes the new argument, in the form of a question, that the reader is asked to think about. Priming an argument through the colloquial use of now or so (e.g. "so, this is a small-scale example") is a common feature in texts making use of a more solidarity-oriented rhetoric.

Interestingly, directives as part of reader-address are also frequently used to position the reader to the discourse rather than some other kind of action. For example, the directives consider, imagine or think were noticeably more common than directives like give or stop. Like with the reference group of the inclusive we, not all actual readers will match the description 
associated with the pronoun you in a given context, and often you can be interpreted as a generic you, much like the impersonal one, or even as referring to the writer. However, I argue that you always has a reader-oriented purpose: opting for you instead of $I$ increases the level of reader engagement and persuasion, whereas opting for you instead of the impersonal one signals a more conversational tone and familiarity with the reader.

\subsection{Intertextuality}

The final extracted factor, Factor 4, also consists of only one metadiscourse marker category, attributors. Attributors are reporting verbs (say, suggest, report) used to source a statement to an outside source. As such Factor 4 is unlike the previous three factors in that it does not relate to the reader or the writer personas. Factor 4 is labelled Intertextuality because its function links the author's text into a wider discourse. Attribution, of course, is important for distinguishing paraphrased content from the writer's personal thoughts. However, attributors also link content to an outside source to signify the writer's involvement in a larger discourse community or it may mark familiarity with the latest developments of a topic, naturally important in a journalistic context. In the present dataset, examples of these are instances where a statement is attributed to a newspaper or a television report. Meanwhile, many statements were also attributed to people of some political or societal power.

Through word choice, attribution is also used to evaluate the attributed content (see e.g. Hunston 2000). If the author deems the individual a respectable and trustworthy authority, the attribution may be used to add persuasive force. Crismore et al (1993: 52-53) argue that persuasive force may be the intention also when sources of less authority are acknowledged. However, at times only context reveals that even neutral attributors (e.g. according to) are used to attribute a statement to a source the author considers unreliable. For instance, in the extract below statements by Hillary Rodham Clinton, then presidential candidate, are evaluated by the author as admissions and claims, both words that suggest Clinton being dishonest:

(6) While Clinton admitted at the debate more U.S. intervention in Syria would have the aim of creating leverage vis a vis Russia, Clinton and the other intervention advocates generally cite the humanitarian crisis in Aleppo as their motivating factor, claiming that Russia and Syrian forces were bombing populated civilian areas under the control of rebel groups (Reason.com: 14.10.2016). 
Only one neutral quoting verb (cite) is used. The others are examples of words evaluate the source as unreliable, thus attributing this evaluation also to Clinton herself. Their purpose can be seen as a reporting function rather than an authority function. By evaluating the reported speech, the author may instead increase the authoritativeness of their own voice.

\subsection{Comparison across opinion writing}

A key purpose of this paper is to discuss differences in the use of metadiscourse across the genre of opinion texts in online journalism, chiefly by comparing the sub-genres blogs, news sites and newspapers. The comparison here is chiefly quantitative as the factor score, or dimension score, for each text can be used to describe how much above or below the mean the text uses a certain dimensional function. It is worth noting that the result thus portrays relative differences within this set of data, not absolute measures comparable to other genres.

The majority of the dimension scores in the corpus fall within a limited range, which indicates a certain homogeneity in the data, suggesting that the sub-genres indeed are similar. This supports the assumption that all three sub-genres can be thought of as representative of the opinion writing genre in modern media, that is, the old traditional genre is not inherently different from the digital media genres including (semi-)professional blogs. However, as all tests in the corpus should be thought of as representative of the population, the texts that fall outside of this area indicate noteworthy trends towards wider use of a certain function. To answer the second research question, the following discussion focuses on differences between the subgenres. In Figure 1, the data have been divided into quadrants. The sub-genre distribution within the quadrant, that is, how many texts of one-genre fall in a set quadrant, illustrates the rhetorical strategies and the main differences within genres. 

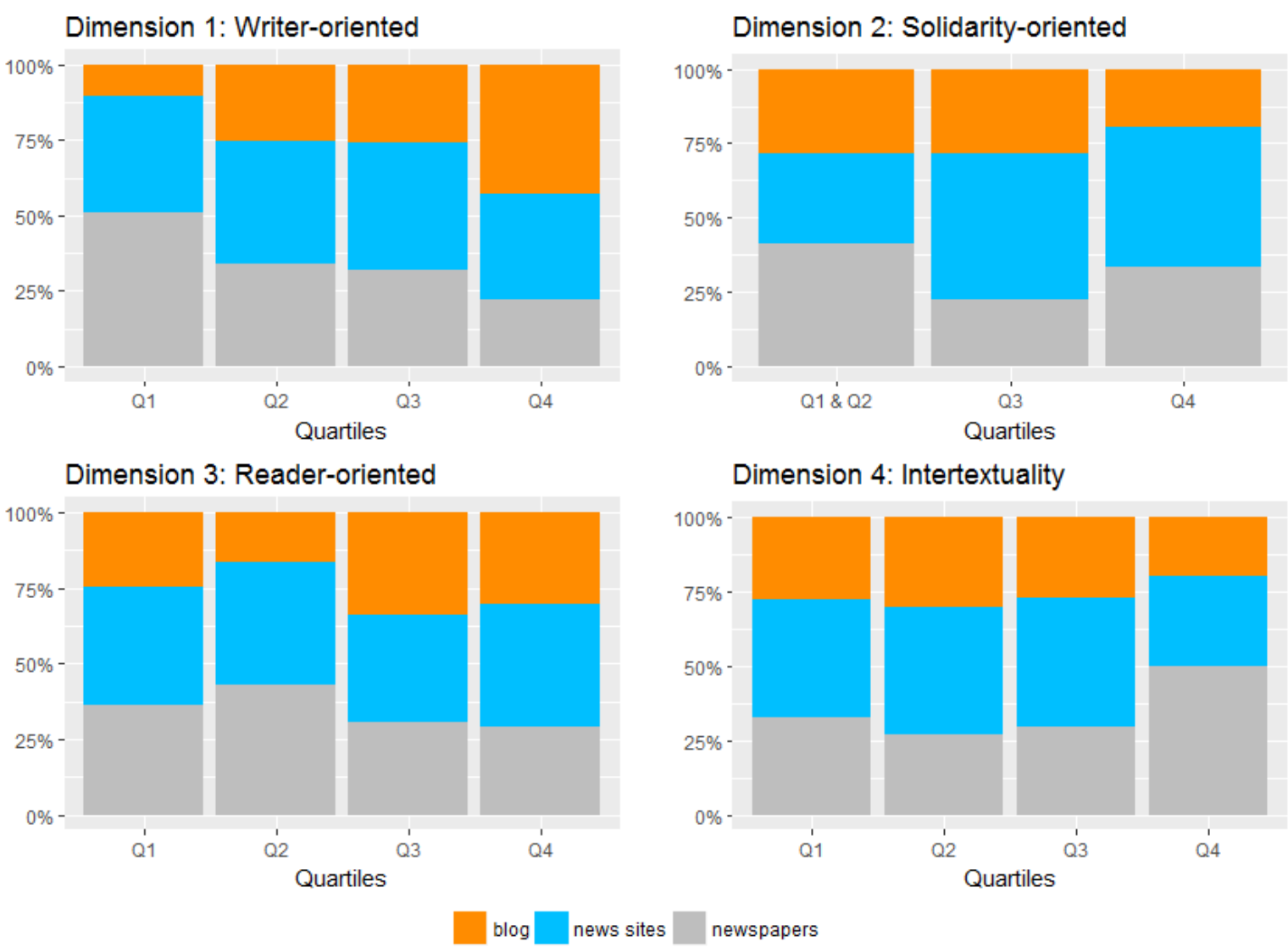

Figure 1. Dimension scores of texts divided into quartiles

Observe that the median of the Solidarity-oriented dimension is so low that quartiles Q1 and Q2 (0-50\%) have had to be combined. This indicates that most texts have a low score in the Solidarity-oriented function.

On the other hand, individual texts can also be plotted in a more fine-grained analysis as in the figure below, which illustrates individual features on two functionally opposing dimensions, the Writer-oriented and the Reader-oriented dimensions. 


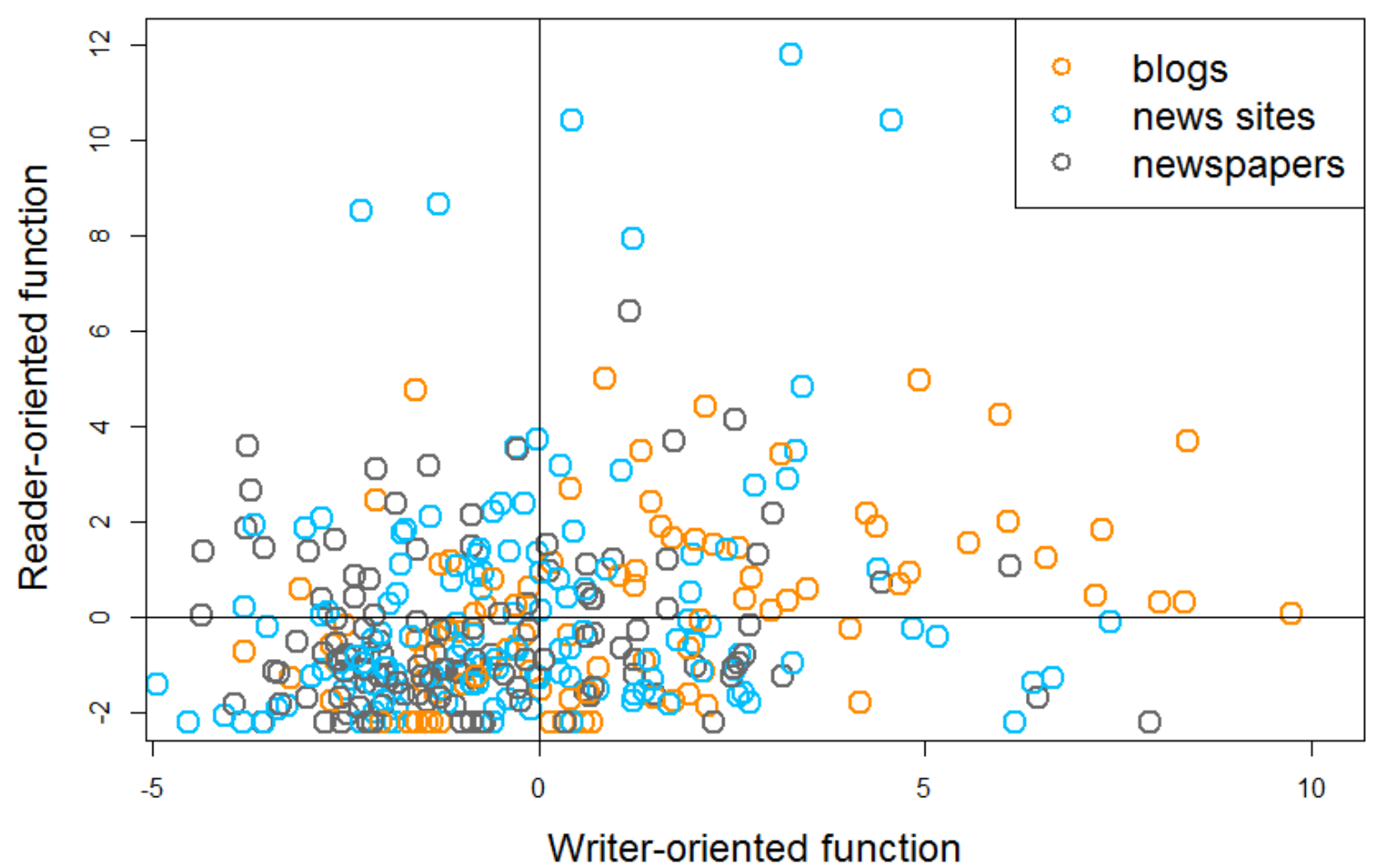

Figure 2. Dimension scores of texts across Reader-oriented and Writer-oriented functions

According to the data, blogs are more likely to use Writer-oriented strategies than the two other sub-genres. As may be seen in Figure 1, only $10 \%$ of texts in the lowest scoring quadrant were blogs, compared to the $43 \%$ in the highest quadrant. Meanwhile, Figure 2 shows that out of the ten highest scoring texts, seven were blogs. This is perhaps unsurprising, considering how blogs are known for their personal and opinionated soap-box style (Wall 2005). While many blogs also use Reader-oriented rhetoric, they were also found to generally have lower scores in using Solidarity-function. Blog authors thus appear to be more concerned with communicating their own view than with addressing the reader, speaking for themselves rather than for any group they represent. Blogs can be seen as having a more opinionated than argumentative function, perhaps because the main audience consists of regular readers assumed to be already inclined to agree. Generally speaking, blogs score lower in the Intertextuality-function than newspapers.

News sites have the highest mean-score in Solidarity-orientedness and represent $47 \%$ of the texts in the top-most quartile. News sites also score quite high in Reader-orientedness and are represented by the highest scoring texts in this dimension. Some texts from news sites also 
score high in Writer-orientedness, indicating some overlap with blogs. On the other hand, news sites generally make more use of Solidarity than blogs, being highly visible in the two highest quadrants in Figure 2. This suggests that news sites are more concerned with the reader than blogs. Whether addressing the reader as separate from the writer or uniting the reader and the writer under the same pronoun, news sites engage the reader and tend to make less reference to the self. Of course, at times references overlap. The following extract, taken from a Barbadosbased news site, is a typical example of both a Solidarity-oriented "we"-group and a Readeroriented "you"-group engaged through a call-to-action:

(7) Our local suppliers should not wait for the phone to go. Be more proactive, let the entire tourism industry know what you can supply, have an up-to-date website [...] (Barbados underground: 29.9.2016).

Our refers to Barbadosians and may refer to suppliers and non-suppliers alike, creating a broader target audience. However, the directive in the second sentence is a call-to-action aimed at a specific group, suppliers in Barbados, and signals a more specific target audience for the text.

A reader-engaging rhetorical strategy is not as common in texts from print newspapers; newspapers also score low in the Writer-oriented dimension. Across the four dimensions extracted, newspapers feature heavily in Intertextuality when compared to the other sub-genres, representing $51 \%$ of the highest quartile, but score low in the rhetorical strategies referring to discourse participants. Although the texts from newspapers are of the same opinionative genre, they employ a rhetorical function that is noticeably different from that observed on news sites. This style, low in pronouns but high in attributors, is what for example Puschmann (2013:101) terms Topic-centric. In Topic-centric texts the reader-writer interaction is minimal or implicit. Instead, the focus is on the content and the facts presented about it. In general, newspapers as a sub-genre seem to contain the least variation in terms of the Writer-, Reader- or Solidarityoriented functions: all texts are limited to a lower range. Interestingly, this range overlaps also with the heaviest cluster of blogs and news sites (see lower-left corner of Figure 2). This indicates that newspapers as the traditional media still set the norms and expectations for other journalistic genres, whether online or offline. 


\section{Discussion}

The above sections have described differences in the use of the metadiscoursal rhetorical strategies in blogs, news sites and newspapers. What might cause the differences, especially the contrast between the rhetoric used on news sites and that used in newspapers, two genres that on the surface appear similar? As the texts of the corpus have been limited to discussions societal and political issues, topic should not play a significant role. Author preferences aside, the explanatory variable is here assumed to be linked to the mode and setting, that is, print versus webpage. One possible explanation is that, as the form of traditional media, print newspapers are even in their online form more likely to retain the traditional journalistic tone of objectivity and detachment, letting the reader make their own judgement (see Greenberg, 2000). However, as noted above, newspapers do often evaluate the topics they report, and in a genre such as columns or op-eds evaluation would only be expected. Based on the findings outlined above, one could hypothesise the following: when the texts do contain evaluation, such as authorial attitudes or the hedging or boosting of the epistemic value, they are typically concisely woven into the prepositional level of the discourse implicitly through word choice, metaphors or modifying adjectives rather extra-clausal adjuncts, that is, through strategies beyond the metadiscourse framework, something to be tackled by future, qualitative research.

Meanwhile, the news sites' goal to engage the reader through explicit pronouns might be a conscious deviation from the style of the traditional media and a desire to imitate the intimate style perceived typical to online registers. However, it should be noted that also the journalists for news sites usually report being highly committed to their profession (Deuze 2017); a rhetoric diverging from the tone perceived as traditional should thus not be seen as a deprecation of the tone upheld by legacy media, which also contains variation. As such, a likely explanation would be that the rhetoric used on small news sites reflects the readership, which, as with blogs, is likely more limited than for widespread newspapers. An audience with a more narrow ideological, demographical and perhaps geographical range (as discussed by Tewksbury [2005]) is presumably ideologically closer to the author, which calls for proximity also in the discourse. An audience predisposed to agree with the writer is more willing to let themselves be united under a joint we-pronoun. Several of the news sites in the present corpus are small: as with bloggers, news site journalists, too, may perceive the regular audience to whom they cater as co-creators of the content. The formal distinction between non-personal blogs and small news sites thus becomes blurred. 
The differences in the Intertextuality-function in blogs and news sites compared to newspapers might indicate a lower use of sources. Essentially, newspapers can be perceived as making more use of sources, either as the topic of the text (an article reporting a politician's statement) or as authoritative backups of claims. However, low Intertextuality could also be linked to the affordances of the online environment, of which the digital native sources would have taken fuller advantage. It is possible that where newspapers use attributors, blogs and news sites prefer to embed their sources through hyperlinks and to omit explicit markers. This hypothesis is supported by De Maeyer (2012), who notes that online journalists do enjoy the use of hyperlink but are aware that traditional style journalism should limit its use. Newspapers' use of Attributors may thus reflect their care in linking. Of course, verification of this hypothesis would require counting frequencies of hyperlinks in the original texts, which falls outside the scope of the present study. One popular source for both popular and authoritative voices is tweets, messages posted on micro-blog site Twitter, which are often embedded simply as an image, but which links the quote to both a name and a date, making other attribution optional.

As the rhetorical strategy of choice relates to target audience, it can be hypothesised that there is a connection between the dimensions and the political ideology represented by the text. For this, comparisons between similar sites were done by comparing mean dimension scores for the sites. For example, the corpus included texts from two UK news sites with clear party leanings, one being a site supportive of the Conservative Party, the other being run by a volunteer collective of Liberal Democrat members. However, while the conservative site had a higher mean dimension score in the Writer-oriented than in the Reader-oriented dimension (1.83 and -0.65 respectively) and the liberal site a lower score in the Writer-oriented than in the Reader-oriented dimension (1.26 and 0.55), high standard deviations within texts from the sites suggest that rhetorical choices are more likely tied to individual writers or topics than site. Likewise, comparison of the mean dimension scores for three US based left-leaning news sites, reveal little of interest. Future investigations of the potential relationship between metadiscourse and ideology would require a more specialised corpus of more openly partisan news sources. Similarly, based on the present dataset, geography, such as UK/US regional differences, also seem to be of little significance.

It was noted that the corporate blogs had lower scores for the three interactive dimensions, but so did the blog of an individual blogger. While said blogger's background as a professional columnist could explain the style imitating newspaper discourse, this hypothesis is difficult to compare based on quantitative as there are also other professional writers in the corpus, whose strategies are noticeably more writer- or reader-oriented. Furthermore, most bloggers also show 
internal variation. The best way to investigate these issues further may be close-reading combined with surveying the writers' own perspectives on the matter.

\section{Conclusions}

This paper suggests that the frequencies of metadiscourse marker categories correlate in ways that can be interpreted as rhetoric strategies or functions. Metadiscourse in opinion writing in online news genres co-occur as functions related largely to how the author acknowledges the presence of (1) themselves as a private person or a writer and evaluator, (2) the presence of the reader who must be guided and engaged by the discourse, and (3) the unity between themselves and the audience as part of the same national or ideological group. The fourth rhetoric function relates to the need of an opinionative text to support its arguments by referring to authoritative sources, or at least by reporting on the statements of authorities as part of an interpretive report.

If a communicative purpose (see Swales 1990) sets the norms for the register of a text, then similar registers can be expected to be found both in texts from the same genre as well as texts from formally different genres that share the communicative purpose. This paper has explored the differences and similarities of texts that share the opinionative and/or persuasive goal and the online setting. The key difference of the analysed texts is the type of news commentary setting. Yet, in terms of text-organising and reader-engaging metadiscourse, the texts of the present corpus are largely similar. It is noteworthy that the genre is defined more by readerengaging interactional than interactive text-organising interactive metadiscourse. The metadiscourse framework of the present study was initially meant to include more textorganising categories, but low overall frequencies of the text-organising variables forced the merging of categories with similar functions as a MDA would otherwise not have been fruitful. Thus, the main functions of the rhetoric strategies observed are defined by reader-engaging interactional metadiscourse. While influential metadiscourse taxonomies (e.g. Crismore et al. 1993; Hyland 2005) do not distinguish between the pronoun we as Self-mention or Inclusive, the results of the present study show that, as is noted e.g. by Ädel (2006), some distinction is important because self-mentions and the inclusive we have rather different functions and occur in different texts, as suggested by their slightly negative co-correlation.

While MDA is already an established method in analysing grammatical variables, its use in pragmatics or macro-level discourse linguistics is still at its beginning. As mentioned, Zhang (2017) uses the method to study metadiscourse. Meanwhile, Precht (2000) uses the method to study stance, another framework on text evaluation. This study joins the ranks by showing how 
MDA as a method is suitable also for gauging the range of variation in a smaller and more specialised corpus. MDA allows for a quantitative analysis that yields statistically significant patterns not visible through qualitative methods. Of course, quantitative analyses are best complemented by a qualitative analysis, and hopefully the results of the present study can be used to inform future studies in online news genres and in metadiscourse theory and methodology.

\section{Acknowledgements}

This article is based on the author's 2017 MA thesis defended at the Department of Languages at the University of Helsinki. The author would like to thank all who have given her feedback on the thesis - during or after its writing - or papers based on it.

\section{Appendix}

The examples have been taken from the following sources part of the corpus. Permission to republish extracts from the texts as examples has been kindly granted by the copyright holders.

- Barbadosunderground.wordpress.com: "The Adrian Loveridge Column - Improving the Link Between Tourism and Agriculture". Published: 29.9.2016

- Bloggernews.net: "Saint Anthony's rises from the ashes!". Published: 14.9.2016

- Bloggernews.net: "The Affect A.I. Is Having On The People". Published: 5.10.2016

- Ericmargolis.com: "Truth about 9/11". Published: 10.9.2016

- Mahablog.com: "Hillary's night?”. Published: 27.9.2016

- Reason.com: "No-Fly Zone in Syria Is a No Good Idea”. Published: 14.10.2016

\section{References}

Ädel, Annelie (2006). Metadiscourse in L1 and L2 English. Amsterdam: John Benjamins Publishing Co.

Biber, Douglas (1988). Variation across speech and writing. Cambridge: Cambridge University Press.

Crismore, Avon, Rodney Farnsworth (1989). "Mr. Darwin and his readers: Exploring interpersonal metadiscourse as a dimension of ethos." Rhetoric Review, 8(1); 91-112. http://doi.org/10.1080/07350198909388880

Crismore, Avon, Raija Markkanen, Margaret S. Steffensen (1993). "Metadiscourse in persuasive writing: A study of texts written by American and Finnish university students." Written communication. 10(1); 39-71. http://dx.doi.org/10.1177/0741088393010001002 
Dafouz-Milne, Emma (2003). "Metadiscourse revisited: A contrastive study of persuasive writing through professional discourse." Estudios Ingleses De La Universidad Complutense. 11; 29-52. http://dx.doi.org/10.5209/rev_EIUC.2003.v11.8792

Dafouz-Milne, Emma (2008). "The pragmatic role of textual and interpersonal metadiscourse markers in the construction and attainment of persuasion: A cross-linguistic study of newspaper discourse." Journal of Pragmatics. 40(1); 95-113. http://doi.org/10.1016/j.pragma.2007.10.003

Deuze, Mark (2017). "Considering a possible future for Digital Journalism." Revista Mediterránea de Comunicación: Mediterranean Journal of Communication. 8(1); 9-18. http://dx.doi.org/10.14198/MEDCOM2017.8.1.1

De Maeyer, Juliette (2012). "The Journalistic Hyperlink.” Journalism Practice. 6(5-6); 692701. http://dx.doi.org/10.1080/17512786.2012.667273

De Waal, Ester, Klaus Schoenbach (2010). "News sites' position in the mediascape: Uses, evaluations and media displacement effects over time." New Media \& Society. 12(3), 477496. http://dx.doi.org/10.1177/1461444809341859

$\mathrm{Fu}$, Xiaoli, Ken Hyland (2014). "Interaction in two journalistic genres: a study of interactional metadiscourse." $\quad$ English Text Construction. $\quad 7(1) ; \quad$ 122-144. http://dx.doi.org/10.1075/etc.7.1.05fu

Fuertes-Olivera, Pedro A., Marisol Velasco-Sacristán, Ascensión Arribas-Baño, Eva Samaniego-Fernández. (2001). "Persuasion and advertising English: Metadiscourse in slogans and headlines." Journal of pragmatics. 33(8); 1291-1307. http://doi.org/10.1016/S0378-2166(01)80026-6

Greenberg, Joshua (2000). "Opinion discourse and Canadian newspapers: The case of the Chinese "boat people"." Canadian Journal of Communication. 25(4); 517-537. http://doi.org/10.22230/cjc.2000v25n4a1178

Halliday, Michael A. K. (1973). Explorations in the Functions of Language. New York: Elsevier-North Holland.

Herring, Susan (2013). “Discourse in Web 2.0: Familiar, Reconfigured, and Emergent.” [In:] Deborah Tannen, Anna Marie Trester (eds.), Discourse 2.0: Language and New Media. Washington DC: Georgetown University Press;1-26.

Hunston, Susan (2000). "Evaluation and the Planes of Discourse: Status and Value in Persuasive Texts." [In:] Susan Hunston, Geoff Thompson (eds.), Evaluation in Text: Authorial Stance and the Construction of Discourse. Oxford: Oxford University Press; 176-207. 
Hyland, Ken (1998). "Persuasion and context: The pragmatics of academic metadiscourse." Journal of pragmatics. 30(4), 437-455. http://doi.org/10.1016/s0378-2166(98)00009-5

Hyland, Ken (2005). Metadiscourse: Exploring interaction in writing. London: Continuum.

Hyland, Ken, Polly Tse (2004). "Metadiscourse in academic writing: A reappraisal." Applied Linguistics. 25(2); 156-177. http://dx.doi.org/10.1093/applin/25.2.156

Ifantidou, Elly (2005). "The semantics and pragmatics of metadiscourse." Journal of Pragmatics. 37(9); 1325-1353. http://dx.doi.org/10.1016/j.pragma.2004.11.006

Kassambara, Alboukadel, Fabian Mundt (2017). "factoextra: Extract and Visualize the Results of Multivariate Data Analyses." Retrieved from: http://cran.rproject.org/package=factoextra Date: 25.2 .2018

Khabbazi-Oskouei, Leila (2013). "Propositional or non-propositional, that is the question: A new approach to analyzing 'interpersonal metadiscourse' in editorials." Journal of Pragmatics. 47(1); 93-107. http://dx.doi.org/10.1016/j.pragma.2012.12.003

Le, Elisabeth (2004). "Active participation within written argumentation: Metadiscourse and editorialist's authority." Journal of Pragmatics. 36(4); 687-714. http://dx.doi.org/10.1016/S0378-2166(03)00032-8

Lenhart, Amanda, Kristen Purcell, Aaron Smith, Kathryn Zickuhr (2010). "Social Media \& Mobile Internet Use among Teens and Young Adults.” Pew Research Centre. Retrieved from: pewinternet.org/Reports/2010/Social-Media-and-Young-Adults.aspx Date: 25.2.2018

Lu, Kristine, Jesse Holcomb (2010). ’Digital News - Revenue: Fact Sheet.” [In:] Pew Research Center, State of the News Media 2016. Retrieved from: http://assets.pewresearch.org/wpcontent/uploads/sites/13/2016/06/30143308/state-of-the-news-media-report-2016final.pdf Date: 25.2.2018

Mauranen, Anna. (1993). Cultural Differences in Academic Rhetoric: A Textlinguistic Study. Frankfurt am Main: Peter Lang.

Myers, Greg (2010). Discourse of blogs and wikis. London: Continuum.

O'Donnell, Michael (2008). “The UAM CorpusTool: Software for corpus annotation and exploration." Proceedings of the XXVI Congreso de AESLA, Almeria, Spain, 3-5 April 2008.

Pett, Marjorie A., Nancy R. Lackey, John J. Sullivan (2003). Making sense of factor analysis. London: SAGE Publications Ltd

Pinjamaa, Noora, Coye Cheshire (2016). "Blogs in a changing social media environment: perspectives on the future of blogging in Scandinavia." Twenty-Fourth European 
Conference on Information Systems (ECIS), Istanbul, Turkey. pp. 1-16. Retrieved from: https://aisel.aisnet.org/ecis2016_rp/17 Date: 27.2.2018

Precht, K. (2000). "Patterns of stance in English." PhD dissertation, Northern Arizona University.

Puschmann, Cornelius (2013). "Blogging.” [In:] Susan Herring, Dieter Stein, Tuija Virtanen (eds.). Pragmatics of Computer-Mediated Communication. Berlin: De Gruyter Mouton; 83-108.

Reese, Stephen D., Lou Rutigliano, Kideuk Hyun, Jaekwan Jeong. (2007). "Mapping the blogosphere professional and citizen-based media in the global news arena." Journalism. 8(3); 235-261. http://doi.org/10.1177/1464884907076459

Rivers, William L., Bruce McIntyre, Alison Work. (1988). Writing Opinion: Editorials. Ames, IW: Iowa State University Press.

Swales, John M. (1990). Genre analysis: English in academic and research setting. Cambridge: Cambridge University Press.

Tewksbury, David (2005). 'The seeds of audience fragmentation: Specialization in the use of online news sites." Journal of broadcasting \& electronic media. 49(3), 332-348. http://dx.doi.org/10.1207/s15506878jobem4903_5

Thompson, Geoff, Susan Hunston (2000). “Evaluation: An Introduction.” [In:] Susan Hunston, Geoff Thompson (eds.). Evaluation in Text: Authorial Stance and the Construction of Discourse. Oxford: Oxford University Press; 1-27.

Thompson, Geoff, Puleng Thetela (1995). "The sound of one hand clapping: The management of interaction in written discourse." Text-Interdisciplinary Journal for the Study of Discourse. 15(1); 103-128. http://dx.doi.org/10.1515/text.1.1995.15.1.103

Vande Kopple, William J. (1985). "Some exploratory discourse on metadiscourse." College Composition and Communication, 36(1); 82-93. http://dx.doi.org/10.2307/357609

Wall, Melissa (2005). “'Blogs of war': Weblogs as news.” Journalism. 6(2); 153-172. http://dx.doi.org/10.1177/1464884905051006

Zhang, Man (2016). “A multidimensional analysis of metadiscourse markers across written registers." Discourse $\quad$ Studies. 204-222. http://dx.doi.org/10.1177/1461445615623907 